\title{
Erratum to: 2011 - year of the bold step?
}

\author{
Øystein E. Olsen • Catherine M. Owens
}

Published online: 6 August 2011

(C) Springer-Verlag 2011

Erratum to: Pediatr Radiol (2011) 41:799-800

DOI 10.1007/s00247-011-2138-8

References 1 and 2 need to be updated. Complete bibliographical information is as follows:

1. Andronikou S, Mngomezulu V (2011) Paediatric radiology seen from Africa. Part II: recognising research advantages in a developing country. Pediatr Radiol $41: 826-831$

2. Andronikou S, McHugh K, Abdurahman N et al (2011) Paediatric radiology seen from Africa. Part I: providing diagnostic imaging to a young population. Pediatr Radiol 41:811-825

The online version of the original article can be found at http://dx.doi. org/10.1007/s00247-011-2138-8

Ø. E. Olsen $(\bowtie) \cdot$ C. M. Owens

Great Ormond Street Hospital for Children NHS Trust,

Great Ormond Street,

London WC1N 3JH, UK

e-mail: oeolsen.pedrad@me.com 